\title{
Five-star Hotel Reception Process Optimization on the Basis of Differentiation
}

\author{
Yuanling $\mathrm{AO}^{1}$ \\ ${ }^{1}$ The Engineering \&Technical College of Chengdu University of Technology, Leshan, Sichuan \\ Province, China
}

Keywords: differentiation; five-star hotel; reception service; process optimization.

\begin{abstract}
With the continuous development of hotel industry in China, personnel of five-star hotels need to provide better services to attract guests. Through differentiation, personnel of five-star hotels can provide guests with personalized services, which can not only improve the quality of reception service, but also improve the market competitiveness of the hotel, and guarantee the sustainable development of the hotel. Therefore, this paper discusses the issue of service process optimization in five-star hotels from the perspective of differentiation, and hopes to provide valuable references for hotel service.
\end{abstract}

\section{Introduction}

With the increasing demands from customers, the services of five-star hotel are becoming more and more humanized. In recent years, the market access threshold of hotel industry is relatively low. A large number of hotel enterprises in the market lead to fierce competition. Only hotels with good service qualities are able to seize the market. Therefore, in addition to standardized and professional services, five-star hotels also need to provide differentiated services to meet the needs of different individuals. Reception service shows the image of a hotel. [1] In order to represent the service advantages of five-star hotels, the whole process of reception service should be optimized to provide customers with differentiated reception services.

\section{Differentiation Theory and the Reception Service of Hotels}

The concept of Differentiation Theory. Differentiation Theory was put forward by Michael E. Porter in his book Competitive Strategy. In this book, Porter discussed the development strategy of enterprises in detail, and put forward to a few basic strategies of competition: differentiation, overall cost leadership and focus. Porter believes that the core of differentiation is that, an enterprise can provide customers with valuable services which cannot be provided by its competitors. The enterprise can meet individual needs of customers through these unique services, and improve its service quality through differentiation. Essentially, differentiation comes from activities carried out in the process of enterprise management. These activities have certain impacts on customers. However, differentiation raises the cost of enterprise activities. But the author explains that, differentiation on service will bring more benefits to the enterprise. For five-star hotels, the essence of service is to provide more personalized services. Through improving the quality of reception service, five-star hotel can create differentiation which separates it from other hotels. This kind of service should become service standard of the hotel. The service standard will bring great value to the hotel. Customers will be attracted by such services and choose to stay in the hotel. It should be said that, differentiation means to create a unique value through the enterprise, and to meet it through using standards or signal standards. [2]

Reception service process of five-star hotels. Rules and regulations are necessary in operation and management processes of every industry. Hotel enterprises also need to standardize their operation process to provide customers with high quality services. The order of services should be fixed to make the whole service process go smoothly and save customers' time when they check in the hotel. For five-star hotels, the reception service process determines the service quality, and it should be analyzed from more perspectives, and then executed with more clear targets. In a sense, after 
deciding the targets of reception service, staffs need to follow the decision; they cannot change these goals.

The reception service process of five star hotels can be divided into following aspects. (1) Smiling, greeting and watching guests. (2) Asking whether the guest has a reservation. (3) Asking the guest to present relevant documents and check in. (4) Holding the registration form on the top side, and putting the pen under the registration form. Handing the form over to the customer and asking the guest to fill in the blanks. (5) Verifying customer's documents, checking whether they belong to the guest. (6) Scanning documents and saving data. (7) Carefully checking the registration form. Explaining blank items, and asking the customer to fill the blanks. (8) Asking whether the customer need to deposit valuable belongings. If necessary, asking the customer to register and sign. (9) For customers who drive to the hotel, asking the license number and notifying relevant departments. (10) Asking payment methods. (11) Looking at the customer with smile, giving the customer with documents, room card and deposit receipt; telling specific location and path of the room. (12) When the guest has big size luggage, providing baggage handling services through relevant staff. (13) After the guest leaving the reception, informing the housekeeping center and typing the check-in information.

The charging process of five-star hotels can be divided into the following steps. (1) Asking the customer to provide deposit. (2) Numbering the deposit and typing information into the computer. (3) Informing housekeeping center. (4) Recording the guest's consumption items carefully. (5) Calculating costs, providing a list and returning the deposit to the customer.

The ushering process of five-star hotels can be divided into the following steps. (1) When individual travelers check in the hotel, the bell attendant should greet the guest initiatively, and provide baggage service. (2) Guiding the guest to reception desk for registration. (3) After the check-in procedure, the bell attendant should lead the customer to the room. He can use this period of time to tell the customer about entertainment, catering and other service areas of the hotel. (4) When arrives the room, the bell attendant should put down the luggage, and ask the customer to check the number of baggage. All baggage must be handled carefully and in order. Informing customer valuables can be deposited.

\section{Problems Existing in Reception Service Process of Five-star Hotels}

Reception service process is not complete and lack of flexibility. The reception service is the image of a five-star hotel. The lack of a complete service process will lead to disordered customer service. The customer will leave the hotel or complain relevant staffs for they are unable to provide professional and standardized services. The current process of five-star hotel reception service is relatively complete, but lack of flexibility. [3] Under that situation, staffs cannot provide differentiated services for customers. Due to the lack of flexibility, some details of reception service are ignored.

The process of reception service is lack of cohesion. The reception service processes of some five-star hotels are slow and not smooth. The whole process is lack of cohesion .The main reason for this problem is that, staffs are lack of teamwork spirit. Staffs in different positions only care about their own work. The serious problem on cohesion will cause abnormal phenomena in the hotel service. Such environment will give customers bad impressions. Staffs are unable to provide differentiated services.

Reception personnel do not pay attention to details in service process. As the saying goes, detail decides success or failure, especially in the current fierce competition of the hotel market. Every detail has become the key to improve service quality and provide differentiated services. In addition to supporting facilities, the competition of five-star hotels also lies in service quality. Better service can help the hotel to gain competiveness in the market. But some five-star hotels do not pay attention to details in service process. Customers cannot enjoy good services of the hotel, let alone differentiated services. Thus, they will lose interests in the hotel. 


\section{Five-star Hotel Reception Process Optimization on the Basis of Differentiation}

Optimization reception management of five-star hotels. In order to provide differentiated services better, managers of five star hotels should adjust the structure of reception. Reception service relates to many departments including information desk, assistant manager, usher, business center and room center. All departments are required to pay attention to details, and establish a strong sense of service, in order to leave a good first impression to customers. In addition, staffs in AM position of five-star hotels must have strong communication skills. Personnel in AM position need to serve VIP customers, and they also represent the hotel image. When there are customer complaints, good psychological qualities are necessary in solving the contradiction between the hotel and the customer. In addition, the service quality of booking department also needs to be improved through optimization. When making a reservation call, the customer can get a preliminary understanding of the hotel. In order to leave a good impression to the customer, relevant staffs should be trained to improve service quality. Their voices and utterances should accord with standardized provisions. Many hotels do not pay attention to ushers, but their services are equally important. Apart from consulting, they also provide baggage services for guests. For them, a good sense of service is necessary, too. In five-star hotels, in order to provide differentiated services, staffs need to grasp good communication skills in foreign languages. At the same time, they also need to have a very careful understanding on the hotel's business scope and room location. [4]

Optimization reception targets of five-star hotels. Reception service of five-star hotels should give guests a relaxing impression. Guests should feel at home when they enter the hotel. In all links of reception services, staffs are face-to-face with customers, and they may feel some pressure. If a relaxed atmosphere is created, staffs will be able to smile in front of guests, and provide personalized services. Only when they provide high quality services for every guest, can guests enjoy differentiated services. So, the optimization of the five-star hotel reception target asks managers to timely change their management ideas. Every reception staff should set up his or her service targets. Through their innovation, hotel services can be more diversified. Then the hotel will be characterized and separated with other competitors. Its competitiveness in the market will be strengthened.

Optimization reception purposes of five-star hotels. Reception service of five star hotels should have its own purposes. When designing specific service purposes, we need to learn rules and regulations from well-known hotels. However, in the process of learning, it is necessary to combine them with the characteristics of our own hotel, in order to provide guests with the unique humanistic care. Many hotel reception services are lack of humane care. In the service management optimization process, the hotel's unique humanistic care should be considered.

Optimization communication mechanism between reception staffs of five-star hotels. In the daily management of hotel, it is necessary to establish a communication mechanism between staffs. Through communication, managers can better understand the development needs of staffs, and control their negative emotions. The informal organization of hotel reception team should be guided correctly. The so-called informal organization is a small group in which people have relatively good relations. Guidance on their work is very important for hotel reception. If the management procedure is handled improperly, the hotel management will be seriously impacted. If one member of the informal organization resigns, some other members of the team will resign, too. The hotel will suffer talent loss. Therefore, when optimizing the communication mechanism, voices of relevant personnel should be heard to set communication goals and needs. Reception staffs should be correct guided according to their performances. Reception staffs should be helped to form a sense of belonging to the hotel, and provide advice and suggestions on reception process optimization. Then more differentiated services will be created. Thus, the hotel will get sustainable development.

\section{Conclusion}

To sum up, differentiated service of five-star hotels is an effective way to separate the hotel with other competitors. In the practical work, we should pay attention to humanistic care through diversified and flexible management. Reception staffs should be helped to form a sense of belonging 
to the hotel, and set up service consciousness through correct guidance. Only in this way, can five-star hotels achieve brand effects and win the stable development.

\section{References}

[1] S.Y. Lv, Z.Q. Zheng, M.M. Li, J.Y. Zhang, B. Guo, Z.H. Yin, Study on the influence factors of reception services in hotels, J. Tourism Tribune . 10 (2014).

[2] Y.R. Li, Analysis of Jin reception service quality improvement strategy of Jinchen International Hotel, J. Science \& Technology Vision. 01 (2014).

[3] X.B. Ou-yang, Analysis of quality problems of hotel reception services, J. Business Economy. 24 (2013).

[4] J.W. Wu, The selection of reception staff in high star-level hotels, J. Journal of Changchun University of Science and Technology. 07 (2011). 